\title{
A practical means of setting the scene for evaluating aggregated absorption risk in EU co-funded programmes related to project failure
}

\author{
Balázs Mezősi \\ National Development Consulting Zrt., Budapest \\ balazs.mezosi@ndczrt.hu
}

\begin{abstract}
SUMMARY
The main purpose of the mid-term evaluation of grant programmes is to assess relevance, progress, effectiveness and efficiency. There are several methodologies, tools and techniques applied in various evaluations to assess these programme aspects. An important area of the evaluation of both the financial progress and the effectiveness of the programme is to evaluate the risk of absorption which is indicated by various factors, inter alia risk of supported project failure. If a project fails in any EU co-funded programme in the stage of preparation or implementation, then the fund already committed to that particular project (assumed to have already been absorbed or "spent") is to be reused again or is to face decommitment (funds have to be paid back to the EU). There are strict EU regulations governing the time scale of this re-use ( $n+2, n+3$ rules), therefore it is of major importance to assess the risk severity (measured as the resultant of the volume of grant at risk and the chance of project failure) and build up an early warning mechanism which indicates if the risk reaches a critical level that requires immediate intervention.
\end{abstract}

Keywords: project, evaluation, risk assessment, mid-term evaluation

\section{ÖSSZEFOGLALÁS}

A támogatási programok közbensö értékelésének fö célja a relevancia, az elörehaladás, az eredményesség és hatékonyság vizsgálata. Számos módszertan, eszköz és technika áll rendelkezésre, mely e szempontok értékelésére használható. Mind a pénzügyi elörehaladás, mind a program eredményesség értékelésének fontos területe az abszorpciós kockázat vizsgálata, melyet számos tényezö, köztük kiemelten a támogatott projektek meghiúsulása eredményezhet. Amennyiben egy projekt megvalósitási szakaszában meghiúsul valamely EU társfinanszirozott programban, akkor az EU forrás, amelyre a tagállam már kötelezettséget vállalt (és így a forrás a már ,elköltöttnek” tekinthetö) újra felhasználásra kell, hogy kerüljön, különben a tagállamnak forrásvesztéssel (az adott támogatás EU-nak való visszafizetésével) kell számolnia. Az ilyen típusú forrás újrafelhasználás idöhorizontjára szigorú uniós szabályozás vonatkozik $(n+2, n+3$ szabályok), ezért kiemelten fontos ennek a kockázatnak (mely a kérdéses támogatási összeg volumenének és a projekt meghiúsulás esélyének eredöjeként definiálható) a megfelelö felmérése, és egy olyan korai elörejelzési rendszer létrehozása, mely jelzi, ha a kockázat olyan kritikus szintet ért el, mely azonnali beavatkozást igényel.

Kulcsszavak: projekt, értékelés, kockázat értékelés, közbenső értékelés

\section{INTRODUCTION}

The main purpose of the mid-term evaluation of grant programmes is to assess relevance, progress, effectiveness and efficiency. There are several methodologies, tools and techniques applied in various evaluations to assess these programme aspects. An important area of the evaluation of both the financial progress and the effectiveness of the programme is to evaluate the risk of absorption which is indicated through various factors, inter alia risk of supported project failure.

Financial progress and financial risk assessment of an EU co-funded programme is usually broken down into two distinct phases corresponding to a standard project selection pipeline: 1) the pre-contractual phase contains project selection stages up till contracting, while 2) post-contractual phase covers the process from contracting up till project closure (Figure 1). The assessment of these two phases requires different methods and tools. In this article, a method and practical tool will be described which has been successfully applied on several occasions in the post-contractual phase for project related absorption risk assessment.

As the figure below indicates, the scope of the postcontractual phase covers project implementation and payment as parallel, iterative processes and project closure. This is due to the fact that a supported project generally entails sub-projects, procurements (tenders) which all require separate tendering processes to accomplish.

Figure 1: Pre-contractual and post-contractual phases of a standard project selection process

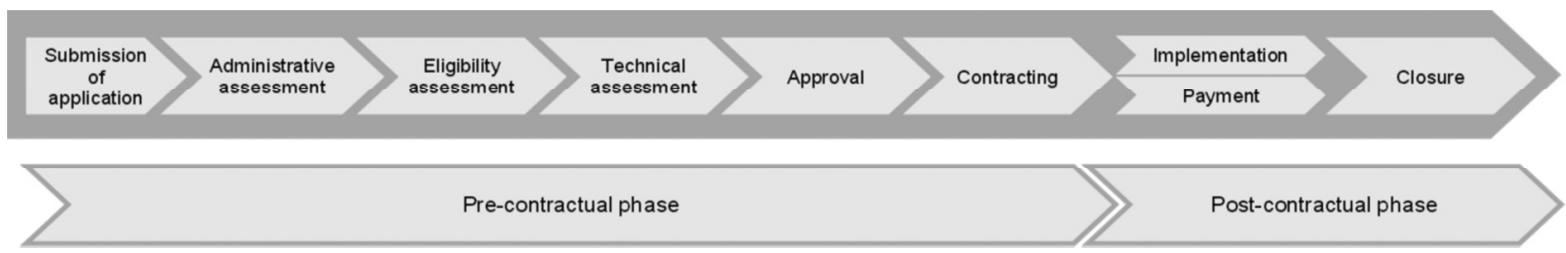




\section{METHODOLOGY OVERVIEW}

The objective of the post-contractual assessment is to review (a sample of selected) projects with a view to gain a multi-faceted insight, based on qualitative information and quantitative data, into possible internal and external factors affecting progress of implementation.

In order to carry out this task it is suggested to use a complex but standard sampling method which combines elements of quota sampling and judgemental sampling based on a set of characteristics and priorities have to be used. In light of the extent of this article, there is no opportunity to go into detail in the sampling methodology.

\section{METHOD}

The methodology to arrive at the number of selected projects is driven mainly by the risk of potential fund de-commitment (EC, 2006). Therefore the underlying bases for project selection are the variables which relate to the risk of losing committed grants.

This approach to the assessment of risk of fund de-commitment is based on a risk adjusted contracted grant amount (hereinafter referred to as RISK SEVERITY), and is derived as follows (Figure 2).

Figure 2: Post-contractual assessment main equation

$$
\begin{array}{r}
\text { RISK SEVERITY = RISK IMPACT } \times \quad \text { RISK FACTOR } \\
\text { (contracted grant amount) } \times \text { (project status; year of project contracting) }
\end{array}
$$

In the above equation RISK IMPACT is the contracted grant amount while RISK FACTOR is a combination of two variables, namely: project status, i.e. Project progress to date and year of approval, i.e. the year in which the $n+2, n+3$ rule starts (EC, 2006). Therefore, the slower the project progress to evaluation cut-off date and the earlier the year of contracting, the higher the risk factor of a project and vice versa.

A measure of risk severity is derived, based on the RISK IMPACT and RISK FACTOR of each project in the sample. All projects can then be ranked in descending order of RISK SEVERITY.

\section{Step 1: Review of sampled projects}

The analysis examines the implementation of contracted projects, with the aim of identifying any process issues which may have hindered implementation of the selected projects. This analysis is usually carried out using a twofold approach comprising of a) planned vs. actual expenditure and b) implementation progress.

The combined results of this analysis may also be used to shed light on the extent of possible funds de-commitment (EC, 1999; EC, 2006).

The planned contracting amounts and disbursements (i.e. payment of grant) are compared with the respective actual amounts reported for each tender within each selected project. This must be done in order to highlight any possible bottlenecks. The following table contains an example of a project with multiple tenders for demonstration purposes.

The $\mathrm{N}$ ratio indicates the extent of the alignment of actual contracting and disbursement amounts of the tenders with those planned at the project contracting stage. Therefore, an $\mathrm{N}$ ratio of 1 indicates perfect alignment, whereas ratios smaller than 1 would highlight delays in contracting or disbursement. Similarly, ratios greater than 1 would imply actual progress in excess of that planned.

The planned versus actual contracting/disbursement schedule analysis is used to arrive at the same analysis of the information at an aggregate level. This analysis sheds some light on the extent of the progress of contracting and disbursement vis-à-vis original planned amounts as well as a profile which may show how projects progress from year ' $\mathrm{N}$ ' going forward (Figure 3).

Figure 3: Calculation of $\mathbf{N}$ ratio of a project

\begin{tabular}{|c|c|c|c|c|c|c|c|c|c|c|c|c|c|c|c|c|c|c|}
\hline & Year & \multicolumn{4}{|c|}{$\mathrm{N}$} & \multicolumn{4}{|c|}{$\mathrm{N}+1$} & \multicolumn{4}{|c|}{$\mathrm{N}+2$} & \multicolumn{4}{|c|}{$\mathrm{N}+3$} & \multirow[b]{2}{*}{ Total } \\
\hline & Quarter & 1 & 2 & 3 & 4 & 1 & 2 & 3 & 4 & 1 & 2 & 3 & 4 & 1 & 2 & 3 & 4 & \\
\hline Planned & Contracting & 0 & 260 & 330 & 1120 & 0 & 0 & 0 & 0 & 0 & 45 & 20 & 0 & 0 & 45 & 0 & 0 & 1820 \\
\hline$(€, 000)$ & Disbursement & 0 & 0 & 60 & 70 & 120 & 120 & 120 & 140 & 140 & 140 & 140 & 140 & 200 & 200 & 200 & 30 & 1820 \\
\hline Actual & Contracting & 0 & 0 & 400 & 200 & 100 & 50 & 0 & 0 & 0 & 0 & 1000 & 0 & 0 & 0 & 0 & 70 & 1820 \\
\hline$(€, 000)$ & Disbursement & 0 & 0 & 0 & 0 & 60 & 70 & 120 & 120 & 120 & 200 & 200 & 200 & 200 & 200 & 200 & 130 & 1820 \\
\hline $\mathrm{N}$ ratio & Contracting & - & - & 0.678 & 0.351 & 0.409 & 0.439 & 0.439 & 0.439 & 0.439 & 0.427 & 0.936 & 0.936 & 0.936 & 0.962 & 0.962 & 1.000 & \\
\hline $\mathrm{N}$ ratio & Disbursement & - & - & - & - & 0.240 & 0.351 & 0.510 & 0.587 & 0.636 & 0.758 & 0.848 & 0.916 & 0.928 & 0.937 & 0.944 & 1.000 & \\
\hline
\end{tabular}

Source: PPCD (2011)

For instance, as shown in Figure 4, project contracting starts at end of quarter 2 and achieves a 0.678 ratio by quarter 3 . Delays manifest themselves in quarter 4 and continue up till quarter 10 . Subsequent quarters demonstrate that the actual cumulative expenditure starts to get in line with the planned expenditure up till project closure. This tool enables to highlight:
- the quarters in which delays act as a bottleneck for the whole project;

- whether the project assessed is on the right track, if not yet completed;

- the extent of the cumulative misalignment, if any, for each quarter. 


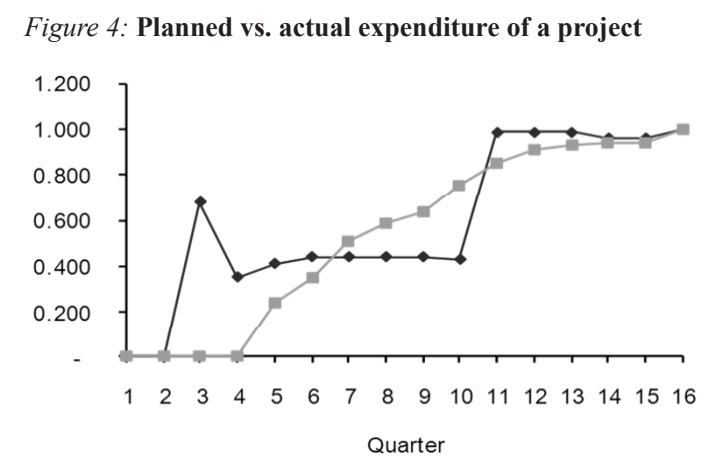

Source: PPCD (2011)

\section{Step 2: Planned vs. actual implementation schedule analysis}

This analysis is carried out to focus on the efficiency of implementation by comparing the planned implementation against actual progress for each project.

The data for each project is used to identify lags or leads (hereafter referred to as lag), for each project stage at tender level, thus highlighting those stages which potentially contributed to delays, and possibly hindered the smooth implementation of projects, and the transition from contracting to disbursements. The resulting estimates of lag can be measured in quarters. The project stages used for this analysis can be based on the standard used in tender progress reports (Figure 5), namely Design (of tender documents), Vetting of tenders prior to publication, Tendering and contracting, Implementation and Closure (PPCD, 2011).

The results can then be used to arrive at an estimate of Scheduled Start Lag, Duration Lag, Stage Specific Lag and Cumulative Lag for each project stage. These lags are defined and estimated as follows:

- Scheduled Start Lag: this refers to the variance between the planned and actual start of the project stage.

- Duration Lag: this refers to the variance between the planned and actual duration of a project stage.

- Stage Specific Lag: this is the total lag that is attributable to a specific project stage. Therefore a lag is stage specific only when it is additional to lags brought forward from previous stages.

- Cumulative Lag: this lag is the total lag of a tender at each project stage. This is calculated as the sum of Stage Specific Lags at the respective project stage. Therefore, for example, the Cumulative Lag at the Tendering and contracting stage is the sum of the stage specific lag of the Design, Vetting and Tendering and contracting stages.

Figure 5: Breakdown of implantation process to Design, Vetting, Tendering and contracting and closure

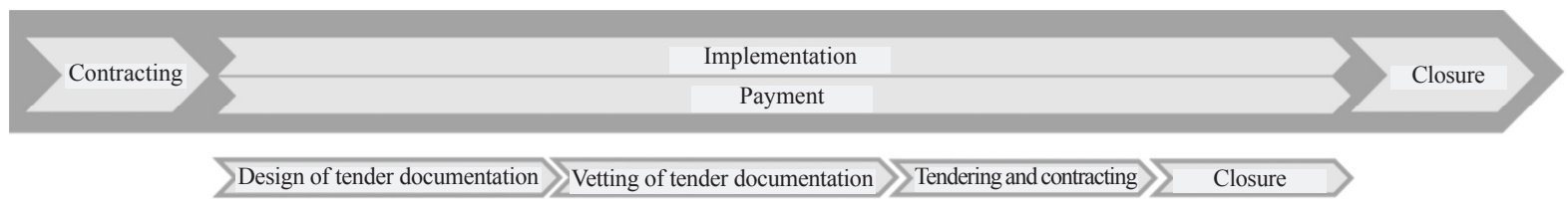

A tool described in Figure 6, illustrating planned versus actual project progress in a Gantt-type format, can be used to determine where the delay is most significant and quantify Project Lag.

The preceding lead time analysis allows the aggregation of the lag figures to provide a snapshot from a higher level. An example is provided below in Figure 7.

Figure 7 above helps to highlight two important aspects.

At project level, it is possible to immediately identify which projects are at risk of fund de-commitment. (EC, 2006; PPCD, 2006). Significant delays in all project stages (example Project D) would signal that part of the committed funds would not be eligible for reimbursement if the project fails to be completed on time. The summation of the RISK IMPACT of these risky projects would give an indication of the total grant amount which is at risk

At stage level, it is possible to identify where attention needs to be directed with a view of eliminating inefficiencies (and hence improving timely effectiveness) and reducing time lags within specific tendering or project stages.

\section{Figure 6: Planned vs. actual implementation schedules}

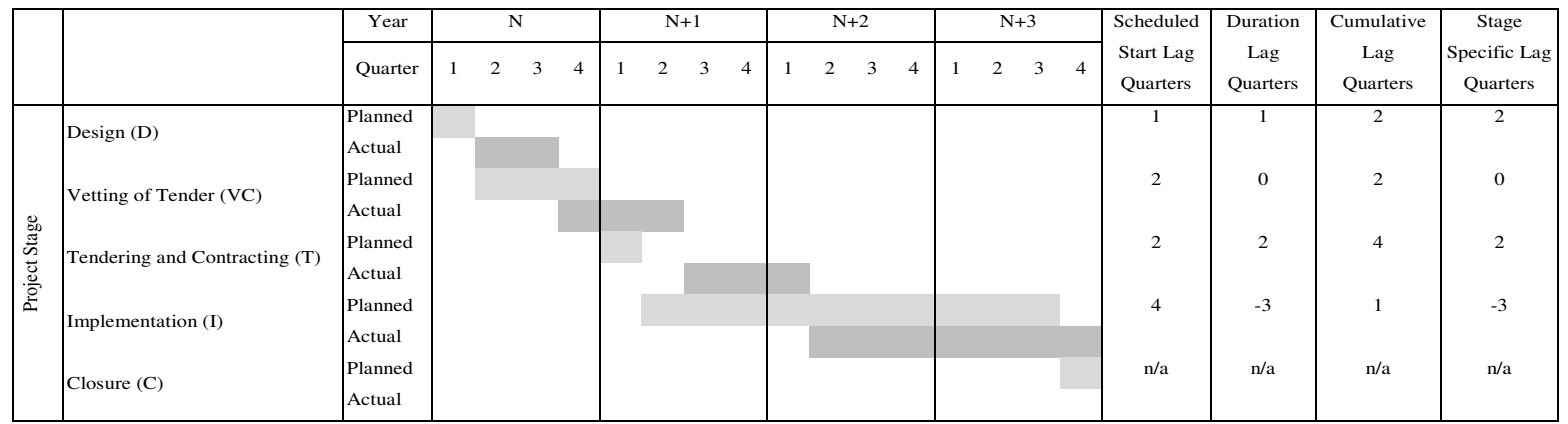

Source: PPCD (2011) 
Figure 7: Stage specific lag - a summary of results

\begin{tabular}{|lccccc|}
\hline & $\begin{array}{c}\text { Design (D) } \\
\text { Quarters }\end{array}$ & $\begin{array}{c}\text { Vetting of Tender } \\
\text { (VC) } \\
\text { Quarters }\end{array}$ & $\begin{array}{c}\text { Tendering and } \\
\text { Contracting (T) } \\
\text { Quarters }\end{array}$ & $\begin{array}{c}\text { Implementation (I) } \\
\text { Quarters }\end{array}$ & $\begin{array}{c}\text { Closure (C) } \\
\text { Quarters }\end{array}$ \\
\hline Project A & 2 & 0 & 2 & -3 & 0 \\
Project B & 1 & 0 & 4 & 2 & \\
Project C & 2 & 2 & 3 & 5 & \\
Project D & 3 & 4 & 5 & 0 & \\
Project E & 2 & 3 & 1 & 1.17 \\
Project F & 1 & 1 & 3.33 & 0.00 \\
Mean & 1.83 & 1.67 & 5.00 & 1.00 \\
Mode & 2.00 & 0.00 & 3.50 & 2.79 \\
Median & 2.00 & 1.50 & 1.63 & \\
Standard Deviation & 0.75 & 1.63 & & \\
\hline
\end{tabular}

Source: PPCD (2011)

\section{SUMMARY}

The application of the above introduced methodology addresses two questions. First, it answers the question of "How much is at risk?", which is described through the extent of variance between planned and actual contracting/ disbursement amounts. Second, the methodology addresses the question of "Where does the risk come from?", showing which tendering or project stage is prevalent in the delay.

However, this analysis is not capable of disclosing the reasons behind the delay. These reasons might be investigated through interviews or direct surveys with stakeholders, i.e. project owners, their suppliers and relevant authorities. Still, the tool described is applicable for evaluation purposes, or, it can be integrated into a monitoring and reporting system so that an early warning system or a sound basis for an on-going evaluation can be developed.

\section{ACKNOWLEDGEMENTS}

The idea of the methodology published in this paper dates back to 2010 and is the honour of Jan Grech. I have had the pleasure to work with Jan for several years developing together this methodology and tool using his idea and I have had the opportunity of testing it in a few more EU co-funded programme evaluations in the 2007-2013 period. My special thank goes to Jan Grech for his idea, to the officials of the Planning \& Priorities Coordination Department of the Maltese government and KPMG for providing a framework for the development.

\section{REFERENCES}

(EC) Council regulation No. 1260/1999 of 21 June 1999 laying down general provisions on the Structural Funds (1999): Official Journal of the European Communities. L161: 1.

(EC) Council regulation No. 1083/2006 of 11 July 2006 laying down general provisions on the European Regional Development Fund, the European Social Fund and the Cohesion Fund and repealing Regulation (EC) No 1260/1999 (2006): Official Journal of the European Communities. L210: 25.

Mid-term Evaluation Report Operational Programme I. (Cohesion Policy 2007-2013) (2011): Planning \& Priorities Coordination Department. Malta.
Mid-term Evaluation Report Operational Programme II. (Cohesion Policy 2007-2013) (2011): Planning \& Priorities Coordination Department. Malta.

National Strategic Reference Framework Malta 2007-2013 (2006) Planning \& Priorities Coordination Department. Malta.

Working Document No.1 (2006): The New Programming Period 2007-2013. Indicative Guidelines on Evaluation Methods: Ex ante Evaluation. European Commission. Directorate General Regional Policy. 